Journal of Industrial and Engineering System (JIES)

e-ISSN: 2722-7979

Vol. 1 No. 2, Hal 75-88

\title{
Lingkungan Kerja Ergonomis dalam Perspektif Disabilitas (Literature Review) ${ }^{1 *}$ Prasidananto Nur Santoso \\ Teknik Industri Departement Teknik Industri, Sekolah Tinggi Teknologi Adisutjipto Yogyakarta e-mail: ${ }^{1}$ prasidananto@stta.ac.id \\ * Korespondensi: prasidananto@stta.ac.id
}

\begin{abstract}
Global facts currently there are about fifteen percent of the world's population who have disabilities. They are among the largest minority groups in the world and about eighty-two percent of them are in developing countries with life below the poverty line and facing limited access in all areas of life, while there is the fact that excluding persons with disabilities from the workforce can result in losing a country's GDP in the amount of three to seven percent.This preliminary research was carried out in the form of a literature review to find out to what extent (scope) disability issues were accommodated in scientific studies and to find out what work environment evaluation approach was appropriate in order to accommodate workers with disabilities (improvement of accessibility) in accordance with ergonomic principles. It is hoped that further research can be used as a reference in preparing a framework for evaluating an accessible work environment for persons with disabilities.
\end{abstract}

Keywords : literature review, work environment, ergonomics, disabilities

\begin{abstract}
ABSTRAK
Fakta global saat ini terdapat sekitar lima belas persen penduduk dunia yang mengalami disabilitas. Mereka termasuk kelompok minoritas terbesar di dunia dan sekitar delapan puluh dua persen diantaranya berada di negara-negara berkembang dengan kehidupan dibawah garis kemiskinan serta menghadapi keterbatasan akses disegala bidang kehidupan, sementara itu terdapat kenyataan bahwa mengucilkan penyandang disabilitas dari angkatan kerja bisa mengakibatkan kehilangan PDB suatu negara sebesar tiga sampai tujuh persen. Penelitian pendahuluan ini dilakukan dalam bentuk kajian literatur untuk mengetahui sejauh mana (scope) isu disabilitas diakomodir dalam kajian ilmiah dan mengetahui pendekatan evaluasi lingkungan kerja apa yang sesuai agar mampu mengakomodir pekerja disabilitas (improvement of accessibility) sesuai dengan kaidah ergonomika. Diharapkan selanjutnya dapat digunakan pada penelitian lanjutan sebagai acuan dalam penyusunan kerangka kerja (framework) untuk evaluasi lingkungan kerja yang aksesibel bagi penyandang disabilitas
\end{abstract}

Kata Kunci: kajian literatur, lingkungan kerja, ergonomi, disabilitas

\section{PENDAHULUAN}

Fakta global saat ini terdapat sekitar 15 persen jumlah penduduk dunia yang mengalami disabilitas. Mereka termasuk kelompok minoritas terbesar di dunia dan sekitar $82 \%$ diantaranya berada di negaranegara berkembang dengan kehidupan dibawah garis kemiskinan serta menghadapi keterbatasan akses atas kesehatan, pendidikan, pelatihan dan pekerjaan. Mereka yang bekerja umumnya memiliki pendapatan yang lebih kecil dibandingkan para pekerja normal pada sektor perekonomian informal dengan perlindungan sosial yang minim dan bahkan tidak ada sama sekali. Sementara itu terdapat kenyataan bahwa mengucilkan penyandang disabilitas dari angkatan kerja bisa mengakibatkan kehilangan PDB suatu negara sebesar 3 - 7 persen (ILO, 2013).

Fakta di Indonesia menunjukkan adanya kedekatan dengan rata - rata perhitungan WHO, diperkirakan 15 persen penduduk Indonesia $( \pm 24$ juta jiwa) merupakan penyandang disabilitas (JICA, 2015). Berdasar paparan ILO (2013) yang diambil menurut data dari Kementerian Sosial pada tahun 2010, jumlah penyandang disabilitas di Indonesia mencapai 11.580 .117 orang dengan rincian, yaitu: 3.474 .035 orang disabilitas penglihatan, 3.010.830 orang disabilitas fisik, 2.547.626 orang disabilitas pendengaran, 1.389 .614 orang 
Prasidananto Nur Santoso

Submitted: 23/09/2020; Revised: 24/09/2020; Accepted: 02/10/2020; Published: 29/12/2020

disabiltias mental, dan 1.158 .012 orang disabilitas kronis. Secara proporsi jenis disabilitasnya seperti terlihat pada Gambar 1.

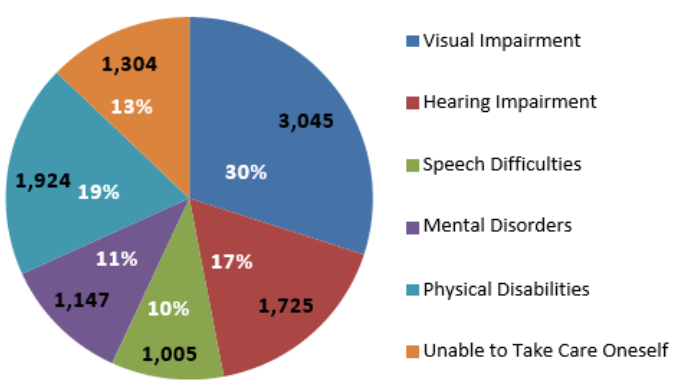

Gambar 1 Pengelompokan berdasarkan jenis disabilitas

(BAPPENAS, 2010)

Tabel 1 Rata - rata populasi disabilitas berdasarkan usia dan jenis kelamin

\begin{tabular}{cccc}
\hline Umur & \multicolumn{3}{c}{$\begin{array}{c}\text { Jenis Kelamin } \\
\text { Wanita } \\
(\%)\end{array}$} \\
\hline $2-4$ & 3.48 & 3.46 & 3.47 \\
$5-9$ & 2.77 & 2.61 & 2.69 \\
$10-14$ & 1.07 & 0.93 & 1.00 \\
$15-19$ & 0.91 & 0.88 & 0.90 \\
$20-24$ & 1.03 & 0.96 & 1.00 \\
$25-29$ & 1.21 & 1.09 & 1.15 \\
$30-34$ & 1.41 & 1.33 & 1.37 \\
$35-39$ & 1.67 & 1.75 & 1.71 \\
$40-44$ & 2.97 & 3.25 & 3.11 \\
$45-49$ & 4.77 & 4.94 & 4.85 \\
$50-54$ & 7.28 & 7.71 & 7.49 \\
$55-59$ & 9.78 & 10.86 & 10.30 \\
$60-64$ & 14.35 & 16.88 & 15.66 \\
$65-69$ & 19.01 & 22.55 & 20.88 \\
$70-74$ & 28.05 & 32.62 & 30.60 \\
$75+$ & 41.17 & 46.52 & 44.28 \\
\hline
\end{tabular}

(BAPPENAS, 2010)

Tabel 2 Penyebab Disabilitas Berdasarkan Laporan Pribadi (\%)

\begin{tabular}{lccccccc}
\hline \multicolumn{1}{r}{ Penyebab } & Seluruh Tipe & Penglihatan & Pendengaran & Kognitif & Komunikasi & Mobilitas & Psiko-Sosial \\
\hline Constitutional & 36.32 & 18.86 & 44.62 & 36.92 & 44.33 & 31.03 & 35.10 \\
Disease & 34.64 & 27.58 & 18.78 & 32.33 & 28.12 & 30.43 & 31.66 \\
Injury/Accident & 17.73 & 12.52 & 9.79 & 9.69 & 7.78 & 16.69 & 11.57 \\
Aging & 16.37 & 31.38 & 22.15 & 10.66 & 8.43 & 8.43 & 8.66 \\
Cursed & 3.44 & 2.22 & 0.64 & 4.23 & 3.28 & 3.27 & 4.23 \\
Unknown & 1.45 & 0.79 & 0.96 & 0.70 & 0.66 & 0.75 & 0.33 \\
Others & 17.59 & 6.66 & 3.05 & 5.46 & 7.40 & 9.39 & 8.46 \\
\hline
\end{tabular}

(FEB UI, 2012) 
Prasidananto Nur Santoso

Submitted: 23/09/2020; Revised: 24/09/2020; Accepted: 02/10/2020; Published: 29/12/2020

Kondisi ketenagakerjaan penyandang disabilitas di Indonesia dapat dilihat pada data yang dikumpulkan melalui sensus tahun 2010.
Tabel 3 menunjukkan status pekerja (usia 1864) berdasarkan tingkat disabilitas, standar pendidikan, dan jenis kelamin.

Tabel 3 Status pekerja (usia 18-64) berdasarkan tingkat disabilitas

\begin{tabular}{llcc}
\hline \multirow{2}{*}{ Sorting Keys } & \multicolumn{2}{c}{ Status/Degree } & \multicolumn{2}{c}{ Working Status } \\
& & Employed & Unemployed \\
\hline Degree of & None & 64.11 & 35.89 \\
Disabilities & Light/Middle & 56.36 & 43.64 \\
& Heavy & 26.42 & 73.58 \\
Educational & Not Finished Primary & 64.95 & 35.05 \\
Standard & Primary Graduate & 65.67 & 34.33 \\
& Secondary Graduate & 62.68 & 37.32 \\
Gender & Male & 83.35 & 16.65 \\
& Female & 43.94 & 56.04 \\
\hline
\end{tabular}

(FEB UI, 2012)

Dalam paparan Markus Sudibyo untuk ILO pada tahun 2002 (Irwanto et al., 2010) disebutkan bahwa, $17 \%$ penyandang disabilitas bekerja di sektor pertanian, $18.6 \%$ di sektor industri, $23.9 \%$ di sektor perdagangan (general trading), dan $13 \%$ di sektor lainnya. Hasil survey ICF (International Classification of Functioning Disability and Health) pada Gambar 2, di 14 propinsi menunjukkan bahwa sebagian besar penyandang disabilitas tidak bekerja (Irwanto et al., 2010).

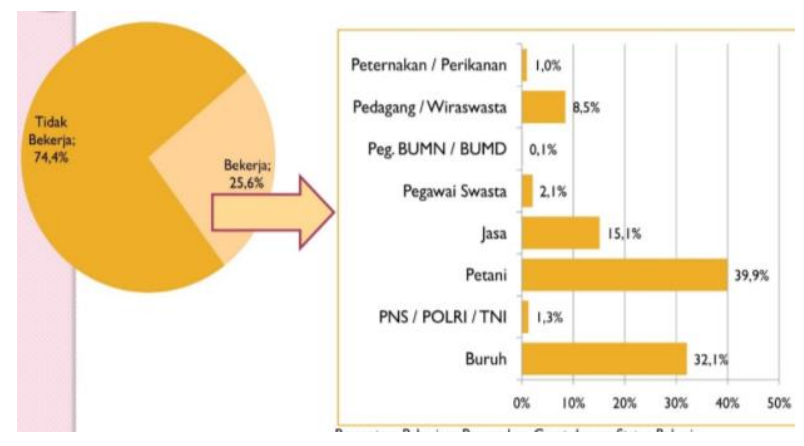

Gambar 2 Jenis pekerjaan penyandang disabilitas (survey ICF)

Di lain pihak, ILO di Indonesia menjalankan program untuk mempromosikan Hak dan Peluang bagi Penyandang Disabilitas dalam Pekerjaan melalui Peraturan Perundangan (PROPEL-Indonesia) yang bertujuan mengatasi masalah kesenjangan dalam hal kebijakan dan perlindungan peraturan perundangan terkait pekerjaan dan pelatihan bagi para penyandang disabilitas guna memastikan kesesuaiannya dengan standar internasional.

Banyak perusahaan mulai menyadari bahwa penyandang disabilitas memiliki potensi untuk produktif dan bisa menjadi karyawan yang mampu diandalkan serta bermanfaat di tempat kerja. Hal itu didukung beberapa dokumen perbandingan produktivitas meliputi tingkat kecelakaan yang lebih rendah dan tingkat retensi pekerjaan antara karyawan penyandang disabilitas dan tenaga kerja umumnya pada sebuah perusahaan. Mempekerjakan penyandang disabilitas dapat memberikan kontribusi secara moral dalam hal keragaman, kreativitas dan kerja secara keseluruhan serta meningkatkan citra perusahaan di antara staf, masyarakat dan di kalangan pelanggan. Beberapa perusahaan juga terlibat dalam pengembangan produk dan layanan untuk disabilitas, keluarga dan temanteman mereka, diantaranya beberapa perusahaan multinasional (Accor, Cisco, Microsoft, dan lain-lain) telah mencoba melakukan proses bisnis berupa pengembangan produk, layanan, dan tanggung jawab sosial perusahaannya (CSR) dari perspektif disabilitas. Tujuan dari penelitian ini adalah Mengetahui ruang lingkup (scope) penelitian tentang isu disabilitas dalam lingkungan kerja, mengetahui pendekatan evaluasi ergonomi yang sesuai untuk lingkungan kerja bagi penyandang disabilitas, dan pada penelitian lanjutan dapat digunakan sebagai acuan dalam penyusunan kerangka kerja (framework) untuk evaluasi lingkungan kerja yang aksesibel bagi penyandang disabilitas.

\section{Disabilitas}

Disabilitas kerja umumnya didefinisikan sebagai waktu kerja yang terhenti, mengurangi produktivitas, dan bekerja dengan keterbatasan 
Prasidananto Nur Santoso

Submitted: 23/09/2020; Revised: 24/09/2020; Accepted: 02/10/2020; Published: 29/12/2020

fungsional sebagai akibat dari kondisi klinis karena trauma ataupun non traumatis. Proses disabilitas yang dipicu oleh kondisi kesehatan sangat dipengaruhi oleh faktor lingkungan dan personal. Faktor lingkungan meliputi sikap sosial, karakteristik sosial, struktur hukum dan sosial, serta iklim dan kondisi wilayah. Sedangkan faktor personal, yaitu: jenis kelamin, usia, cara beradaptasi, latar belakang sosial, pendidikan, profesi, kondisi kesehatan di masa lalu dan saat ini, keseluruhan pola perilaku, kepribadian, dan faktor-faktor lain yang mempengaruhi persepsi disabilitas bagi tiap individu.

Disabilitas bukan berarti kehilangan fungsi secara total pada salah satu dari tiga hal (Gambar 3), misalnya terdapat masalah pada kondisi medis (pada kasus seropositivity untuk Human Immunodeficiency Virus), seseorang masih dapat berfungsi penuh dalam hal aktivitas dan partisipasi.

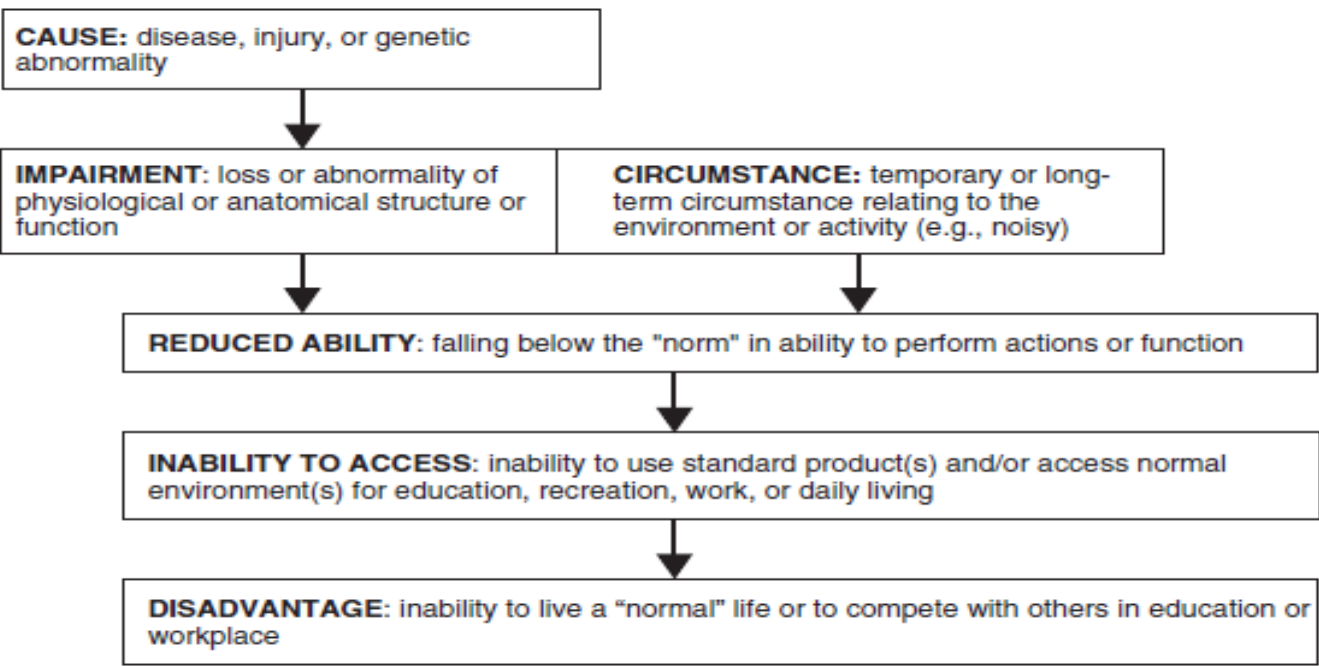

Gambar 4.Model Disabilitas WHO

Dengan demikian, selain membuat produk lebih mudah bagi semua orang untuk digunakan, akan lebih baik lagi bila secara umum desain dan lingkungan mampu mengakomodir bahkan ketika seseorang berada di bawah kondisi ekstrim (stres) sekalipun. Sejalan dengan hal tersebut,

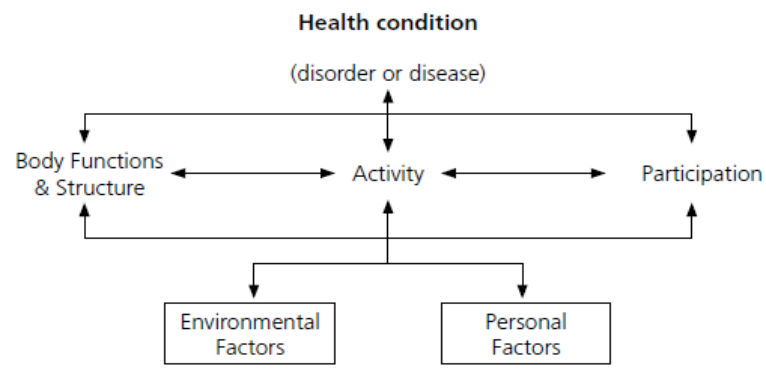

Gambar 3 Interaksi antar komponen disabilitas (ICF Model)

Untuk melihat dampak dari disabilitas dan hubungannya dengan desain universal, maka pendekatan model dari WHO (Gambar 4) sering digunakan sebagai acuan analisis. Model tersebut menunjukkan hubungan antara gangguan fungsional dan desain yang berperan dalam menimbulkan kondisi disabilitas. Selain itu, model tersebut juga menunjukkan bahwa keadaan lingkungan bisa berdampak pada berkurangnya kemampuan seseorang, bahkan pada manusia normal sekalipun. Kombinasi antara buruknya desain dan keadaan lingkungan tersebut dapat menyebabkan situasi dimana seseorang mengalami disabilitas dan ketidakmampuan melaksanakan tugas tertentu.

ergonomi berperan melalui beberapa cara berikut:

1. Mengembangkan teknik-teknik baru, strategi, dan teknologi yang dapat memungkinkan seseorang untuk berkarya lebih baik di tempat kerja, rumah, atau komunitas. 
Prasidananto Nur Santoso

Submitted: 23/09/2020; Revised: 24/09/2020; Accepted: 02/10/2020; Published: 29/12/2020

2. Mengembangkan alat-alat khusus atau teknologi bantu yang dapat menyesuaikan dengan bagian-bagian tertentu dari individu sesuai dengan keterampilan dan kemampuan seseorang.

3. Mengubah desain secara umum sehingga lebih bermanfaat dengan keterampilan dan kemampuan yang lebih meluas.

\section{Ergonomi}

Secara etimologi, ergonomi berasal dari dua kata dalam bahasa Yunani: ergon dan nomos, ergon berarti kerja, sedangkan nomos berarti aturan, kaidah, atau prinsip sehingga ergonomi dapat diartikan sebagai suatu aturan atau norma dalam sistem kerja. Ergonomi merupakan ilmu yang mempelajari sifat, kemampuan, dan keterbatasan manusia agar dapat digunakan untuk merancang suatu sistem kerja sehingga orang dapat hidup dan bekerja pada sistem itu dengan baik dan mencapai tujuan yang diinginkan melalui pekerjaan yang efektif, aman, dan nyaman. International Ergonomics Association mendefinisikan ergonomi sebagai studi tentang aspek - aspek manusia dalam lingkungan kerjanya yang ditinjau secara anatomi, psikologi, rekayasa teknik (engineering), manajemen, dan desain. Ergonomi merupakan kesatuan ilmu, seni, dan teknologi yang berupaya untuk menyerasikan alat, cara, dan lingkungan kerja terhadap kemampuan dan keterbatasan manusia sehingga dapat berkarya secara optimal tanpa mendapat pengaruh buruk dari pekerjaannya. Terdapat sekitar 90 metode yang dapat digunakan untuk analisis ergonomi secara umum dan efektif (Stanton et al., 2004).

Ergonomi dapat dibedakan menjadi 2 jenis, yaitu ergonomi mikro dan ergonomi makro. Ergonomi mikro merupakan kajian ergonomi dalam lingkup kecil atau ergonomi tradisional. Aktivitas menganalisis postur kerja pekerja, menaksir produktivitas, mendesain alat kerja, dan sebagainya dapat dikategorikan sebagai ergonomi mikro. Jadi, ergonomi mikro merupakan pendekatan ergonomi pada suatu proses yang ditujukan khusus pada proses spesifik. Perkembangan keilmuan saat ini melihat bahwa penilaian ergonomi tidak hanya perlu dilakukan dan dianalisis secara mikro saja, tetapi perlu untuk diimplementasikan melalui integrasi pada lingkungan yang lebih besar (organisasi 79 perusahaan) yang dikenal dengan ergonomi makro.

Ergonomi makro melihat tinjauan ergonomi secara luas yang menempatkan sistem produksi sebagai organisasi kerja. Konsep tersebut menunjukkan bahwa ergonomi makro merupakan bidang yang penting untuk diterapkan didalam perusahaan. Karena tujuan organisasi akan dapat tercapai jika didalam organisasi itu sendiri terdapat sistem kerja yang baik. Ergonomi makro akan bermanfaat dan dapat berpengaruh terhadap tingkat produktivitas dari perusahaan itu sendiri.

\section{METODE PENELITIAN}

Agar penelitian terarah sesuai dengan tujuan yang akan dicapai maka penelitian ini dilaksanakan dengan langkah-langkah penelitian mulai dari tahap pendahuluan berupa studi pendahuluan sampai dengan tahap kesimpulan (Gambar 8). Tahapan-tahapan penelitian yang dilakukan pada penelitian ini dari awal hingga akhir, yaitu:

1. Perumusan Masalah

Pada tahap awal dilakukan pemilihan tema yang sesuai dengan isu dan minat penelitian. Permasalahan harus ditulis dengan lengkap dan tepat. Perumusan masalah dilakukan dengan studi literatur pendahuluan untuk memahami gap yang ada dari penelitian terdahulu terkait dengan tema penelitian.

2. Penelusuran Literatur

Pada tahap ini dilakukan penelusuran literatur yang relevan pada jurnal - jurnal ilmiah terakreditasi nasional dan internasional dengan kata kunci sesuai dengan tema penelitian dan selanjutnya dilakukan review secara sistematis. Pada tahap penelusuran ini dilakukan metode penelusuran literatur secara konvensional dengan mencari literatur yang relevan dari daftar pustaka di setiap jurnal/karya ilmiah yang diperoleh.

3. Tinjauan Literatur / Literature Review Tahap kajian literatur dilakukan untuk mengetahui ruang lingkup (scope) penelitian tentang isu disabilitas dalam lingkungan kerja dan mengetahui pendekatan evaluasi ergonomi yang sesuai untuk lingkungan kerja bagi penyandang disabilitas. 
Prasidananto Nur Santoso

Submitted: 23/09/2020; Revised: 24/09/2020; Accepted: 02/10/2020; Published: 29/12/2020

4. Analisis dan Pembahasan

Tahap berikutnya adalah melakukan evaluasi terhadap literatur yang diperoleh dengan melihat kontribusinya terhadap topik yang dibahas. Hasil evaluasi kemudian dianalisis dan dilakukan pembahasan secara sistematis dalam sebuah laporan penelitian. Laporan penelitian ditutup dengan kesimpulan dari hasil analisis data. Tahapan penelitian ini dapat dilihat pada Gambar 5

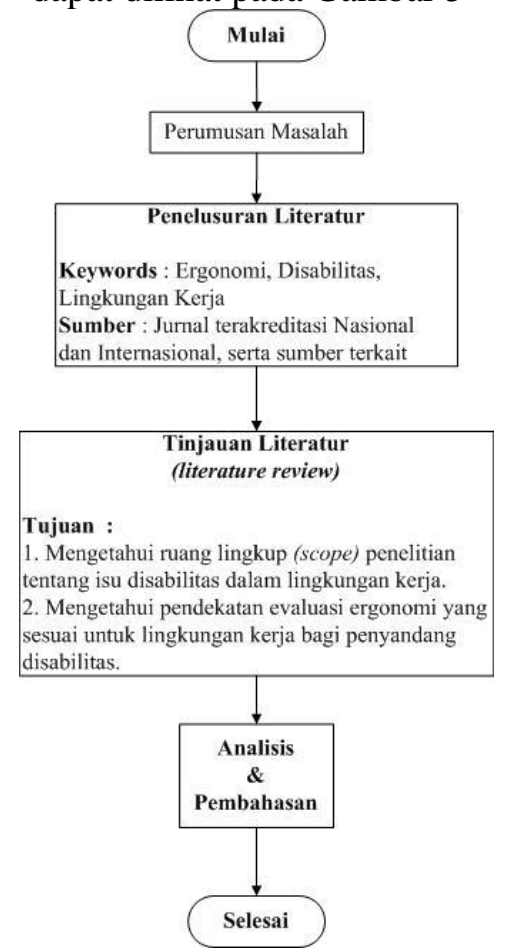

Gambar 5 Diagram Alir Penelitian

\section{HASIL DAN PEMBAHASAN}

Pada penelusuran awal diperoleh 4 jurnal yang relevan sebagai pondasi penelusuran lanjutan, selanjutnya penelusuran jurnal dilakukan dengan mencari jurnal yang relevan pada daftar pustaka yang disitasi dalam keempat jurnal tersebut dengan tetap mempertahankan kata kunci dan batasan tahun penelitian. Langkah tersebut dilakukan sebanyak tiga kali pengulangan secara bertahap seperti tampak pada Gambar 6 . Beberapa hal yang digunakan penulis sebagai panduan dalam memilih literatur yang relevan, antara lain adalah:

1. Kaitan antara analisis/evaluasi ergonomi, lingkungan tempat kerja, dan disabilitas.

2. Kejelasan metodologi dan tujuan riset.

3. Kebaruan riset (up to date).
Kajian literatur dilakukan terhadap total 21 jurnal riset yang dapat diakses untuk mengetahui ruang lingkup (scope) penelitian tentang isu disabilitas dalam lingkungan kerja dan mengetahui pendekatan evaluasi ergonomi yang sesuai untuk lingkungan kerja bagi penyandang disabilitas. Literatur tersebut secara umum merupakan hasil penelitian di beberapa negara yaitu: Amerika Serikat, Brazil, Cina, Indonesia, India, dll.

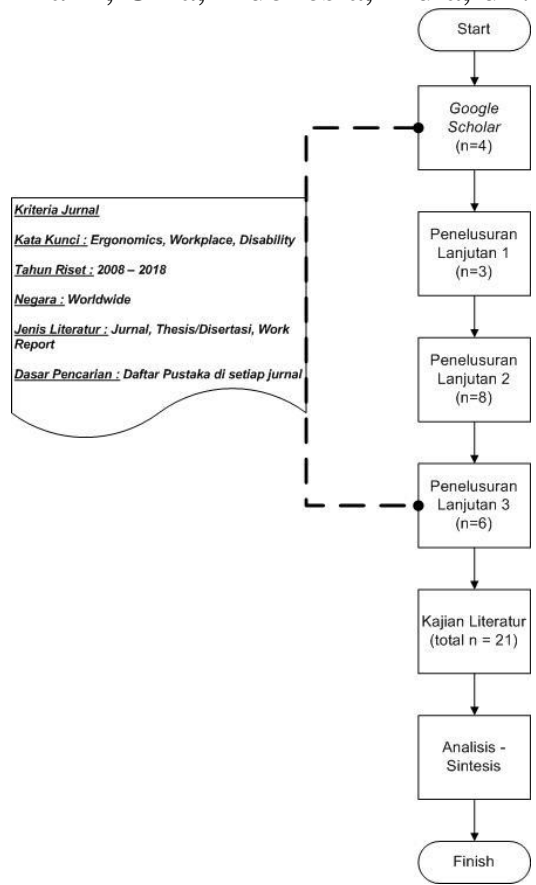

Gambar 6 Diagram Alur Penelusuran Literatur (Jurnal)

\section{PWD Experience (pengalaman pada disabilitas)}

Konteks tersebut banyak membahas mengenai pengalaman yang dialami oleh penyandang disabilitas dalam berbagai hal baik di pekerjaan maupun diluar pekerjaan. (Hernandez et al., 2008) melakukan penelitian secara kualitatif di industri jasa untuk mengetahui persepsi para pekerja terhadap pekerja disabilitas dengan hasil diperoleh 5 pokok utama, yaitu :

1. Pentingnya keberadaan agen penyalur kerja bagi disabilitas, dimana hal itu berperan penting dalam proses penyelarasan antara pengusaha dan pekerja serta membantu pengusaha membuat akomodasi kerja bagi pekerja disabilitasnya. Sisi lain adalah perlunya advokasi bagi disabilitas untuk memberikan kesadaran bagi pengusaha 
Prasidananto Nur Santoso

Submitted: 23/09/2020; Revised: 24/09/2020; Accepted: 02/10/2020; Published: 29/12/2020

agar menjaga komitmen untuk mempekerjakan disabiltias dan mengurangi batasan dalam manajemen.

2. Masih adanya bias manajer yang meliputi ketakutan dalam hal waktu pengawasan yang bertambah, produktivitas yang buruk, dan frekuensi ketidakhadiran yang akan terjadi bila merekrut pekerja disabilitas.

3. Masih minimnya peluang promosi dalam posisi pekerjaan bagi disabilitas. Umumnya pekerja disabilitas ditempatkan di bagian level bawah dengan posisi keahlian yang biasa saja (mengetik, melayani makanan, mencuci, dan lainlain) dan sangat sedikit yang berada di level profesional. Disebutkan bahwa dari 1000 orang pekerja disabilitas, terdapat $17 \%$ yang menolak dipromosikan, karenanya pengusaha memiliki persepsi bahwa pekerja disabilitas merasa nyaman dengan posisi tersebut dan dianggap pekerja disabilitas tidak mengharapkan promosi jabatan apapun.

4. Biaya akomodasi pada pekerja disabilitas pada kenyataannya tidak begitu besar, namun pengusaha memiliki persepsi ketakutan bahwa biaya tersebut dapat membesar.

5. Terdapat banyak keuntungan dalam mempekerjakan disabilitas, diantaranya adalah rendahnya ketidakhadiran dan masa kerja yang panjang. Pekerja disabilitas juga dipersepsikan memiliki sifat loyal, reliable, dan pekerja keras. Keuntungan lain adalah adanya diversifikasi aturan kerja yang berpengaruh pada lingkungan pekerjaan serta mendorong proses inklusi diantara para pekerja melalui perbedaan yang ada.

(Balser et al., 2008)melakukan studi lapangan untuk membangun dan menguji secara empiris terkait dengan model kepuasan pada akomodasi disabilitas. Menggunakan 333 sampel pekerja yang mengajukan permintaan dan menerima akomodasi disabilitas, mereka menyatakan bahwa karakteristik status seperti ras/suku, gender, dan otonomi kerja secara tidak langsung berpengaruh terhadap kepuasan terhadap akomodasi yang diperoleh. Terdapat beberapa implikasi praktis yang dihasilkan dari penelitian mereka, diantaranya adalah pekerja disabilitas merasa lebih puas jika mereka menerima akomodasi yang diminta. Karnanya, tentu saja organisasi/perusahaan harus memahami faktor lain yang berpengaruh dalam memutuskan jenis akomodasi yang harus disediakan. Organisasi juga seharusnya secara jelas memperoleh masukan dari pekerjanya dalam proses akomodasi untuk meningkatkan kepuasan pekerja. Hal terpenting adalah organisasi harus memastikan tidak ada diskriminasi terhadap pekerja disabilitas dan pekerja normal.

(Luecking, 2008) meneliti pandangan pekerja disabilitas dan pengembangan pekerjaan dimasa mendatang. Pekerja disabilitas masih dipandang secara sebelah mata, misalnya disabilitas fisik dianggap lebih baik dibanding pekerja dengan disabilitas intelektual/psikiatrik. Hal itu berpotensi menimbulkan salah pengertian dan diskriminasi dalam proses rekrutmen maupun dalam pekerjaan. (Copeland et al., 2010) menguji reaksi kognitif dan afektif pada para pekerja yang bekerja dengan pekerja disabilitas di tempat kerja, mereka menyatakan bahwa sikap pekerja tidak berhubungan dengan pengetahuan mereka tentang kebijakan legal terhadap disabilitas (ADA). Sikap positif terhadap akomodasi pekerja dan adanya keseimbangan layanan terkait erat dengan keyakinan tentang akomodasi yang cukup beralasan. Reaksi kognitif dan afektif yang negatif terkait dengan tingkat pengalaman bekerja bersama pekerja disabilitas, hal itu menunjukkan bahwa semakin lama bekerja bersama dengan pekerja disabilitas akan mempengaruhi sikap positif mereka dan meningkatkan persepsi positif terhadap disabilitas.

(Bitencourt et al., 2012) menyatakan dalam penelitiannya yang dilakukan di industri sepatu, dengan obyek observasi adalah disabilitas yang terlibat dalam produksi, bahwa proses inklusi disabilitas dapat dijalankan dengan baik dimana hal tersebut ditentukan oleh karakteristik hubungan proses produksi terkait dengan desain sistem kerjanya. Perusahaan sepatu tersebut menggunakan pengelompokan mesin produksi berdasar kesamaan proses (cellular management) sehingga pekerja disabilitas berada pada cell kerja yang selaras dengan kondisinya, didukung dengan ritme produksi yang tidak kaku (tidak berbasis belt conveyor) 
Prasidananto Nur Santoso

Submitted: 23/09/2020; Revised: 24/09/2020; Accepted: 02/10/2020; Published: 29/12/2020

sehingga memungkinkan fleksibilitas ritme produksi (variasi ritme) untuk menghargai perbedaan kondisi pekerja antara yang normal dan pekerja disabilitas.

\section{PWD Perspective (sudut pandang /persepsi disabilitas)}

(Ali et al., 2011) meneliti sudut pandang disabilitas dari sisi jenis pekerjaan yang diinginkan disabilitas. Hasil penelitiannya menunjukkan bahwa rendahnya rasio pekerja disabilitas tidak terkait dengan preferensi kerja. Orang-orang disabilitas memiliki kesamaan dengan orang normal dalam hal mereka juga membutuhkan pekerjaan. Hanya saja para penyandang disabilitas memiliki keterbatasan dalam hal keaktifan mencari pekerjaan dan rendahnya optimisme untuk memperoleh pekerjaan yang sesuai. Hal itu terkait dengan kondisi disabilitasnya ditambah dengan rendahnya pendidikan dan tingkat pelatihan, dimana seringkali bertolak belakang dengan produktivitas yang diharapkan di tempat kerja sehingga peluang untuk mendapatkan pekerjaan yang sesuai sangat minim.

(Kulkarni et al., 2011) menyatakan bahwa terdapat faktor spesifik yang mempengaruhi proses integrasi disabilitas pada lingkungan kerjanya, yaitu peran rekan kerja sangat berpengaruh pada tahap sosialisasi dan merupakan kunci katalis pada proses integrasi. Dukungan rekan kerja tersebut terwujud dalam bentuk penerimaan sosial, dukungan psikososial, dan bantuan dalam memahami dan menyelesaikan pekerjaan. Hal lain yang berpengaruh adalah peran pengawas (supervisor) dimana peran tersebut berkaitan dengan dukungan kerja dan sebagai sumber dukungan informal dalam halhal personal. Dukungan lain yang diperlukan disabilitas dari sisi organisasi yaitu berbentuk fleksibilitas kerja, menyediakan sarana interaksi sosial, pengembangan budaya inklusi, dan peningkatan keahlian/kompetensi bagi disabilitas melalui pelatihan-pelatihan.

\section{PWD Barrier (hambatan pada disabilitas)}

(Shier et al., 2009) menyatakan dalam penelitiannya bahwa penyandang disabilitas masih mengalami hambatan nyata berupa stigmatisasi dan diskriminasi dalam lingkungan kerja maupun kebijakan legal. Hambatan yang dialami terkait dengan proses inklusi sosial adalah sikap dan praduga masyarakat terhadap penyandang disabilitas. Diperlukan kebijakan yang dapat mendukung disabilitas untuk bertahan dalam lingkungan kerja dengan meningkatkan kapasitas kemampuan mereka melalui sarana rehabilitasi dan pelatihan.

(Kulkarni et al., 2014) berpendapat dari hasil penelitiannya bahwa terdapat dua hambatan utama yang dihadapi penyandang disabilitas, yaitu saat sebelum masuk dan sesudah masuk dalam suatu instansi pekerjaan. Hambatan sebelum masuk, antara lain:

1. Hambatan persepsi sikap oleh penguji pada proses rekrutmen yang nampak pada kesan awal terhadap disabilitas sehingga mempengaruhi proses dan hasil akhir ujian masuk kerja.

2. Hambatan self-created merupakan hambatan dari dalam diri penyandang disabilitas yang disebabkan adanya perasaan pesimis terhadap dirinya sendiri.

3. Hambatan dari sisi institusional secara umum terdapat tiga jenis hambatan yang berpengaruh pada disabilitas berupa tekanan coercive (kesetaraan kesempatan), tekanan isomorphic (tekanan serikat pekerja), dan tekanan mimetik (jika organisasi merupakan sebuah konsorsium). Hanya hambatan berupa tekanan coercive yang berpengaruh pada saat proses awal perekrutan.

Setelah penyandang disabilitas diterima dan masuk di suatu perusahaan/organisasi, masih terdapat beberapa hambatan antara lain berupa akomodasi kerja, inklusi sosial, dan karir. Memahami hambatan tersebut akan mengarah ke solusi berbasis fakta dimana individu diberikan kesempatan untuk menggunakan bakat mereka demi kepentingan yang lebih luas.

Uraian tentang disabilitas diatas menunjukkan bahwa penyandang disabilitas dalam kenyataannya mengalami hal yang berbeda dengan persepsi mereka terhadap jenis pekerjaan dan lingkungan kerja yang mereka harapkan. Perbedaan antara persepsi dan harapan tersebut tercermin pada hambatan hambatan yang masih dialami oleh penyandang disabilitas di tempat kerja.

Terkait dengan lingkungan tempat kerja bagi disabilitas terdapat dua konteks utama 
Prasidananto Nur Santoso

Submitted: 23/09/2020; Revised: 24/09/2020; Accepted: 02/10/2020; Published: 29/12/2020

yang menjadi perhatian utama, yaitu akomodasi di tempat kerja dan desain tempat kerja yang ergonomis. Uraian hasil penelitiannya secara rinci adalah sebagai berikut:

\section{Workplace Accomodation (Akomodasi di tempat kerja)}

(Citron et al., 2008) melakukan studi terhadap usaha perubahan sistem melalui proses penyesuaian pekerja yang dilakukan selama 7 tahun oleh program komunitas rehabilitasi untuk mendukung penyandang disabilitas di Georgia. Penyesuaian pekerja disabilitas dapat dilakukan pada saat negosiasi awal antara pekerja disabilitas dan pengusaha dengan melakukan penyesuaian aktivitas kerja melalui metodologi, antara lain:

1. Job carving, membuat suatu tugas dengan memodifikasi satu tugas atau lebih (tugas tertentu) tanpa merubah keseluruhan tugas aslinya.

2. Job negotiation, membuat tugas baru dari beberapa jenis tugas yang berkaitan.

3. Job creation, membuat tugas baru berdasarkan kebutuhan di tempat kerjanya.

4. Job sharing, tugas dilakukan oleh dua atau lebih pekerja yang berbagi tugas yang sama.

5. Self employment, melibatkan penggunaan usaha kecil menengah (UKM).

Metodologi penyesuaian pekerjaan tersebut dapat berhasil bila dilakukan dengan perubahan sistematis yang terencana dengan melibatkan pengembangan staf, pendekatan manajerial dan pengawasan, dan beberapa penyesuaian dalam proses perekrutan SDM. Prinsipnya adalah penyesuaian pekerjaan menjamin bahwa sebuah pekerjaan sesuai dan cocok terhadap minat dan kondisi pekerja.

(Solovieva et al., 2009) membandingkan dua kondisi dari sisi biaya dan manfaat kerja terkait dengan penggunaan akomodasi bagi disabilitas yang melibatkan asisten pribadi (PAS) dan tanpa asisten pribadi (Non-PAS). Temuan utama diperoleh terkait dengan penggunaan biaya untuk PAS dan Non-PAS, dimana pengusaha menyatakan bahwa umumnya biaya akomodasi pada kasus - kasus Non-PAS adalah $\$ 500$, sedangkan umumnya biaya akomodasi untuk kasus kasus PAS adalah $\$ 1,850$. Biaya tahunan untuk akomodasi PAS rata-rata $\$ 8.000 /$ tahun dibandingkan dengan biaya Non-PAS sebesar \$2.000/tahun. Rata-rata jumlah biaya dan manfaat langsungnya adalah $\$ 1.600$ untuk akomodasi PAS dan $\$ 1.500$ untuk Non-PAS. Manfaat akomodasi dengan PAS yang paling sering disebutkan adalah (a) meningkatkan produktivitas, (b) meningkatkan keragaman, (c) retensi karyawan merasa dihargai, (d) meningkatkan interaksi dengan rekan kerja, (e) semakin meningkatkan moral perusahaan, (f) meningkatkan produktivitas total perusahaan. Temuan yang ada meningkatkan kesadaran tentang aspek-aspek biaya dan manfaat terkait dengan akomodasi PAS untuk disabilitas walaupun biaya akomodasi PAS adalah tiga kali lebih besar dari akomodasi Non-PAS. Banyak akomodasi Non-PAS yang bebas biaya bisa dipilih pengusaha diantaranya dengan mengubah jadwal kerja dan memindahkan individu ke lokasi lain yang sesuai dengan kondisi disabilitasnya.

(Solovieva et al., 2011) melakukan studi eksplorasi terhadap akomodasi disabilitas dan keuntungannya. Partisipan yang digunakan merupakan pengusaha dan profesional SDM yang tidak tergabung dalam jaringan akomodasi kerja (JAN-USA). Pengusaha menganggap bahwa manfaat utama yang paling sering disebutkan dalam pelaksanaan akomodasi kerja adalah: (a) mempertahankan karyawan yang berkualitas, (b) meningkatkan produktivitas pekerja, dan (c) menghapus biaya pelatihan karyawan baru. Untuk manfaat tidak langsung yang paling sering dirasakan adalah: (a). meningkatkan interaksi dengan rekan kerja, (b) meningkatkan semangat perusahaan secara keseluruhan, dan (c) peningkatan produktivitas perusahaan secara keseluruhan. Jenis akomodasi yang paling sering diterapkan adalah membeli peralatan dan mengubah jadwal kerja. Sebagian besar responden memperkirakan manfaat langsung dari akomodasi lebih dari \$1.000. Temuan penelitian ini meningkatkan kesadaran tentang manfaat yang diperoleh terkait dengan membuat akomodasi untuk penyandang disabilitas di tempat kerja, dimana beberapa manfaat tersebut memiliki nilai penting bagi bisnis, rekan kerja, dan individu dengan disabilitas.

(Gold et al., 2012) melakukan studi dengan metode diskusi fokus secara berkelompok dan membuat suatu grounded 
theory yang menyatakan bahwa pengusaha berusaha secara efektif untuk memenuhi permintaan akomodasi karyawan dan dari hasil beberapa penelitian khusus lainnya diperoleh bukti empiris bahwa karyawan dan perusahaan bernegosiasi terkait permintaan akomodasi bagi disabilitas. Hasil analisis menemukan bahwa meskipun pengusaha dan pekerja memiliki persepsi tentang negosiasi akomodasi dalam beberapa cara yang masuk akal, namun mereka memiliki perbedaan pada harapan masing - masing (misalnya dari sisi biaya akomodasi versus kewajiban moral untuk menyediakan akomodasi). Perbedaan tersebut menunjukkan bahwa para pengusaha dan karyawan disabilitas harus lebih sadar terhadap perspektif masing-masing, dan lebih meningkatkan wawasan/pendidikan tentang bagaimana mengelola sebuah permintaan akomodasi yang seharusnya diwujudkan untuk meningkatkan retensi pekerjaan dan mengurangi biaya turnover.

(Nevala et al., 2015) melakukan review sistematis untuk meninjau efektivitas akomodasi kerja terkait dengan ketenagakerjaan, kemampuan bekerja, dan kaitan biaya-manfaat diantara para penyandang disabilitas. Tiga analisa kuantitatif (satu acak terkontrol, satu dikendalikan bersamaan, dan satu berkelompok) dan delapan studi kualitatif berhasil memenuhi kriteria inklusi yang menunjukkan bahwa terdapat beberapa jenis akomodasi kerja tertentu (berupa konseling dan bimbingan, pendidikan dan advokasi diri, membantu orang lain, perubahan jadwal kerja, organisasi kerja dan transportasi khusus) terbukti secara moderat mendukung kinerja pada disabilitas dan mengurangi biaya. Fasilitator kunci dan hambatan pekerjaan yaitu self advocacy, dukungan dari pengusaha dan masyarakat, jumlah pelatihan dan konseling, dan fleksibilitas jadwal kerja serta organisasi kerja.

(Chi et al., 2018) fokus meneliti akomodasi kerja dengan mencari cara bagaimana membagi pekerjaan/tugas menjadi beberapa bagian/unsur yang mampu dikerjakan oleh penyandang disabilitas intelektual dan psikiatrik, sehingga dapat memberikan upah yang sesuai dengan kinerjanya. Untuk meraih tujuan tersebut, maka dilakukan analisa tugas, daftar periksa, dan analisis tata letak stasiun kerja pada dua jenis workshop yang berbeda. Proses penelititannya dilakukan melalui beberapa tahap, yaitu: pada tahap awal sebelum mengusulkan akomodasi yang layak bagi penyandang disabilitas, maka dilakukan evaluasi terhadap pekerjaan (job analysis) pada pekerja penyandang disabilitas terlebih dahulu. Hal itu untuk mengidentifikasi ketidaksesuaian antara jenis tugas dan kapasitas kerja penyandang disabilitas. Penelitian dilakukan dengan observasi, penerapan daftar periksa Hierarchial Task Analysis (HTA), dan Work Performance Rating Scale yang menghasilkan pembuatan SOP dan penataan ulang stasiun kerja perakitan sehingga terjadi kesesuaian antara pekerja disabilitas, stasiun kerja, dan beban kerjanya.

\section{Ergonomics Workplace Design (Desain tempat kerja ergonomis)}

(Leyshon et al., 2010) melakukan studi literatur secara sistematis dengan menggunakan dasar penelitiannya dari kenyataan telah tersedia secara luas bukti empiris adanya intervensi ergonomis di perkantoran/pekerjaan yang menggunakan komputer, tetapi hanya sedikit bukti yang mendukung penggunaannya pada pekerja yang memiliki gangguan muskuloskeletal (MSD). Hasil tinjauan literatur yang dilakukannya menunjukkan bahwa terdapat beberapa intervensi ergonomis untuk mencegah disabilitas akibat terjadinya gangguan muskuloskeletal, beberapa diantaranya adalah perlunya kelompok pelatihan dan konseling ergonomi, perlunya modifikasi alat kerja sesuai prinsip ergonomis, dan desain ulang stasiun kerja secara ergonomis. Hal tesebut memiliki tujuan akhir untuk meningkatkan kenyamanan, keselamatan, dan produktivitas pekerja.

(Martins et al., 2012) melakukan pengamatan/observasi langsung terhadap kegiatan dan lingkungan kerja di proyek konstruksi, wawancara dengan pekerja proyek, merekam dengan perangkat video/fotografi untuk menganalisis pekerjaan tukang batu, dan menggunakan perangkat lunak (simulasi) untuk menentukan profil pekerja penyandang disabilitas yang dapat melakukan fungsi pekerjaan tukang batu di proyek konstruksi dan menentukan jenis penyesuaian ergonomis 
yang diperlukannya. Hasil kegiatan pengumpulan data dan analisis persyaratan fisik, kognitif dan organisasi pekerjaan, serta hasil analisis kemampuan fungsional pekerja melalui perangkat lunak (simulasi) pada disabilitas menunjukkan bahwa pekerja dengan gangguan disabilitas pendengaran masih bisa melakukan kegiatan tanpa ada perubahan di tempat kerja dan pekerja dengan disabilitas fisik yang kakinya diamputasi perlu menggunakan prostesis yang sesuai untuk melakukan kegiatan-kegiatan sesuai fungsinya. Hal itu menunjukkan bahwa kegiatan profesional dengan ditunjang penyesuaian ergonomi sangat penting karena adaptasi dalam pekerjaan akan dapat dilakukan oleh pekerja secara memadai.

(Dimberg et al., 2015) melakukan kajian literatur mengenai kemajuan dalam penerapan kaidah - kaidah ergonomi di tempat kerja. Hal tersebut diperlukan agar menumbuhkan partisipasi dan kesadaran langsung dari pihak manajemen perusahaan dan pekerja akan pentingnya penerapan ergonomi dalam mendukung suatu pekerjaan. Manusia memiliki beberapa faktor resiko, yaitu: faktor resiko individual (postur dan ketegangan otot), faktor resiko biomekanik, faktor patofisiologi, faktor psikologi dan sosial, dll. Seiring dengan laju perkembangan teknologi yang semakin pesat dan kemudahan aksesnya, maka diperlukan pula penyesuaian dari sisi ergonomi kerja dengan penerapan sistem manajemen ergonomic.

Pada konteks evaluasi ergonomi terdapat beberapa penelitian di antaranya: (Aubry et al., 2010) yang melakukan penelitian dalam usahanya mengembangkan lingkungan fisik ergonomis bagi disabilitas dengan mengintegrasikan simulator dinamis yang telah ada melalui platform perangkat lunak secara virtual (virtual reality) yang disebut $A R^{\prime} e V I$. Tahapan risetnya dilakukan melalui tiga langkah, yaitu:

1. Identifikasi tempat kerja dan kebutuhan aktivitas kerja terkait disabilitas, termasuk didalamnya analisis NIOSH yang mengukur postur awal (initial posture) dan beban (lifted load).

2. Mengintegrasikan virtual human disabilitas dengan tempat kerja dan aktivitas kerja yang bervariasi.

3. Melakukan analisis ergonomi pada berbagai tahap kerja yang berbeda meliputi task level (tahap tugas), occupational level (tahap postur kerja dan simulasi kerja), dan dynamic level (tahap dinamis) yang melibatkan unsur biomekanis.

Hasilnya mengusulkan sebuah kerangka kerja yang memungkinkan pengembangan gerakan akurat dan analisis ergonomis pada berbagai jenis tahapan pekerjaan yang berbeda termasuk bagi disabilitas.

(Mali et al., 2015) melakukan kajian pustaka secara naratif untuk memberikan review keseluruhan pada literatur yang terkait dengan evaluasi ergonomis di stasiun kerja industri dan menyarankan perbaikan ergonomisnya. Masalah ergonomis yang menjadi contoh evaluasi ergonomi adalah masalah yang dihadapi di industri pengecoran. Prinsip ergonomi berperan penting dalam peningkatan produktivitas operator. Dua faktor utama, yaitu: desain tata letak dan desain kerja sangat penting bagi efisiensi operator. Industri manufaktur saat ini telah menyadari bahwa perbaikan ergonomi stasiun kerja lebih menguntungkan dalam hal penghematan bila dibandingkan dengan investasi biaya daalam bentuk sumberdaya manusia, mesin, bahan dan metode.

(Purnomo et al., 2017) melakukan analisis makro-ergonomi dengan pendekatan desain (macro-ergonomic analysis and design approach/MEAD). MEAD fokus pada pemetaan secara sistematis pada masalah organisasi dan solusi yang melibatkan semua elemen kerja. analisis $M E A D$ terdiri dari 10 tahap sistematis yang dimulai dengan identifikasi sistem kerja dalam organisasi, analisis kerja dan ergonomi, serta diakhiri dengan peningkatan penerapan solusi yang telah diperoleh. Obyek penelitian dilakukan di pusat pelatihan garmen dengan fokus evaluasi pada tempat kerja dan postur kerja. Hasil yang diperoleh dari observasi dan analisis makro ergonomi, yaitu:

1. Integrasi sistem kerja dengan desain ergonomis dibuat untuk menciptakan lingkungan kerja yang menyenangkan dan meningkatkan kompetensi pekerjaan.

2. Desain baru termasuk kursi yang bisa diatur, meja bordir dengan pijakan kaki untuk istirahat, pencahayaan, masker, penyumbat telinga, dan fasilitas air 
Prasidananto Nur Santoso

Submitted: 23/09/2020; Revised: 24/09/2020; Accepted: 02/10/2020; Published: 29/12/2020

minum.

3. Tata letak fasilitas dirancang ulang sesuai urutan proses pekerjaan. Para karyawan juga diberikan kesempatan latihan peregangan sebelum pelatihan kerja dimulai. Hal tersebut dilakukan untuk mencegah resiko kelelahan kerja.

Penyandang disabilitas memiliki harapan yang sama dengan individu normal lainnya terkait dengan pekerjaan. Mereka juga membutuhkan pekerjaan untuk beraktualisasi diri, namun bukti empiris menunjukkan bahwa hingga saat ini masih terdapat hambatan bagi penyandang disabilitas terkait dengan pekerjaan dan fasilitas untuk mendukung pekerjaannya. Penyandang disabilitas masih mengalami persepsi negatif yang berwujud stigmatisasi dan diskriminasi sepihak dari perusahaan dimulai saat proses awal sampai dengan pasca rekrutmen. Hal tersebut berupa kekhawatiran pengusaha terkait dengan biaya akomodasi, persepsi negatif terkait biaya dan manfaat, minimnya peluang promosi, bias manajerial (dalam pengambilan keputusan), dan lain-lain.

Untuk mengatasi berbagai hambatan bagi disabilitas tersebut, diperlukan kesadaran diantara pengusaha dan pekerja disabilitas terhadap perspektif masing - masing pihak. Untuk itu diperlukan edukasi dan kebijakan terkait akomodasi bagi penyandang disabilitas. Beberapa akomodasi yang dapat digunakan untuk mendukung penyandang disabilitas meraih kinerja terbaiknya, yaitu:

1. Menyediakan agen penyalur tenaga yang dapat melatih, mengadvokasi, dan membantu pengusaha membuat akomodasi yang sesuai untuk pekerja disabilitasnya.

2. Manajemen perusahaan dapat membuat program budaya inklusi yang didukung dengan kebijakan perusahaan serta peran aktif rekan kerja dan pengawas (supervisor) untuk mendukung keberhasilan proses integrasi pekerja disabilitas pada lingkungan kerjanya.

3. Terkait dengan ritme pekerjaan, manajemen perusahaan dapat menerapkan penyesuaian jadwal kerja yang fleksibel dengan melakukan variasi ritme produksi sehingga pekerja disabilitas dapat meraih kinerja yang sesuai antara ritme produksi dengan keterbatasannya. 86
4. Terkait dengan aktivitas kerja, manajemen perusahaan dapat membagi tugas menjadi beberapa bagian yang mampu dikerjakan oleh penyandang disabilitas.

Agar akomodasi kerja bagi disabilitas tersebut dapat terwujud diperlukan intervensi ergonomi terkait dengan penentuan jenis fasilitas, desain tata letak fasilitas, desain sistem kerja, dll. Untuk mengintegrasikan hal tersebut diperlukan evaluasi ergonomi secara mikro dan makro yang tujuan akhirnya dapat digunakan untuk membuat suatu sistem manajemen ergonomi.

\section{KESIMPULAN DAN SARAN KESIMPULAN}

Kesimpulan yang dapat diambil dari kajian literatur tersebut adalah penyandang disabilitas memiliki harapan yang sama dengan individu normal terkait dengan kebutuhan fasilitas kerja untuk mendukung kinerjanya, fakta masih menunjukkan adanya hambatan bagi penyandang disabilitas di lingkungan kerja, baik berupa hambatan fisik terkait dengan fasilitas dan dukungan akomodasi kerja maupun hambatan dari sisi non fisik terkait dengan diskriminasi dalam proses inklusi di lingkungan kerja, ergonomi dapat berperan dalam mengakomodir kebutuhan pekerja yang sesuai dengan kondisi penyandang disabilitas melalui desain universal pada sistem dan alat kerja.

\section{SARAN}

Saran yang dapat diberikan berdasarkan kajian literatur tersebut adalah perusahaan dapat mengusahakan untuk mendukung kinerja penyandang disabilitas dengan menyediakan sarana akomodasi kerja yang disesuaikan dengan hasil dari evaluasi dan desain ergonomi di tempat kerja (baik secara makro maupun mikro ergonomi), sistem Manajemen Ergonomi dapat menjadi kerangka dalam mendesain ulang sistem dan alat kerja yang sesuai dengan kebutuhan dan kondisi para pekerja penyandang disabilitas.

\section{DAFTAR PUSTAKA}

Ali, M., Schur, L., \& Blanck, P. (2011). What types of jobs do people with disabilities want? Journal of Occupational Rehabilitation, 21(2), 199-210. https://doi.org/10.1007/s10926-010- 
Prasidananto Nur Santoso

Submitted: 23/09/2020; Revised: 24/09/2020; Accepted: 02/10/2020; Published: 29/12/2020

9266-0

Aubry, M., Julliard, F., \& Gibet, S. (2010). Interactive Ergonomic Analysis of a Physically Disabled Person, s Workplace eric Julliard, Sylvie Gibet To cite this version: Lecture Notes in Computer Science, 255-260.

Balser, D. B., \& Harris, M. M. (2008). Factors affecting employee satisfaction with disability accommodation: A field study. Employee Responsibilities and Rights Journal, 20(1), 13-28. https://doi.org/10.1007/s10672-0079062-y

Bitencourt, R. S., \& De, L. B. (2012). Inclusion of people with disabilities in the production system of a footwear industry. Work, 41(SUPPL.1), 47674774. https://doi.org/10.3233/WOR2012-0027-4767

Chi, C. F., Dewi, R. S., Jang, Y., \& Liu, H. L. (2018). Workplace accommodation for workers with intellectual or psychiatric disabilities. International Journal of Industrial Ergonomics, 68(May), 1-7. https://doi.org/10.1016/j.ergon.2018.06.0 01

Citron, T., Brooks-Lane, N., Crandell, D., Brady, K., Cooper, M., \& Revell, G. (2008). A revolution in the employment process of individuals with disabilities: Customized employment as the catalyst for system change. Journal of Vocational Rehabilitation, 28(3), 169-179.

Copeland, J., Chan, F., Bezyak, J., \& Fraser, R. T. (2010). Assessing cognitive and Affective Reactions of employers toward people with disabilities in the workplace. Journal of Occupational Rehabilitation, 20(4), 427-434. https://doi.org/10.1007/s10926-0099207-y

Dimberg, L., Goldoni Laestadius, J., Ross, S., \& Dimberg, I. (2015). The Changing Face of Office Ergonomics. The Ergonomics Open Journal, 8(1), 38-56. https://doi.org/10.2174/18759343015080 10038

Gold, P. B., Oire, S. N., Fabian, E. S., \& Wewiorski, N. J. (2012). Negotiating reasonable workplace accommodations: Perspectives of employers, employees with disabilities, and rehabilitation service providers. Journal of Vocational Rehabilitation, 37(1), 25-37. https://doi.org/10.3233/JVR-2012-0597

Hernandez, B., McDonald, K., Divilbiss, M., Horin, E., Velcoff, J., \& Donoso, O. (2008). Reflections from employers on the disabled workforce: Focus groups with healthcare, hospitality and retail administrators. Employee Responsibilities and Rights Journal, 20(3), 157-164. https://doi.org/10.1007/s10672-0089063-5

ILO. (2013). Pedoman ILO tentang Pengelolaan Penyandang Disabilitas Di Tempat Kerja. Jakarta: ILO Publication

Irwanto, Rahmi, E., Asmin, K., Fransiska, Lusli, M., Okta, dan Siradj. (2010) Analisis Situasi Penyandang Disabilitas di Indonesia: Sebuah Desk-Review Jakarta: Pusat Kajian Disabilitas FISIPUniversitas Indonesia

JICA. (2015) Data Collection Survey on Disability and Development in Indonesia Final Report. KRI International Corp

Kulkarni, M., \& L.Lengnick-Hall, M. (2011). Socialization of People with Disabilities in The Workplace. Human Resource Management, 50(4), 521-540. https://doi.org/10.1002/hrm

Kulkarni, M., \& Lengnick-Hall, M. L. (2014). Obstacles to Success in the Workplace for People With Disabilities: A Review and Research Agenda. Human Resource Development Review, 13(2), 158-180. https://doi.org/10.1177/15344843134852 29

Leyshon, R., Chalova, K., Gerson, L., Savtchenko, A., Zakrzewski, R., Howie, A., \& Shaw, L. (2010). Ergonomic interventions for office workers with musculoskeletal disorders: A systematic review. Work, 35(3), 335-348. https://doi.org/10.3233/WOR-2010-0994

Luecking, R. G. (2008). Emerging employer views of people with disabilities and the future of job development. Journal of Vocational Rehabilitation, 29(1), 3-13.

Mali, S. ., \& Vyavahare, R. T. (2015). An Ergonomic Evaluation of an Industrial Workstation: A Review. International Journal of Current Engineering and Technology, 5(3), 1820-1826. 
Martins, L. B., Barkokébas Junior, B., \& Guimarães, B. M. (2012). Including the people with disabilities at work: A case study of the job of bricklayer in civil construction in Brazil. Work, 41(SUPPL.1), 4716-4721. https://doi.org/10.3233/WOR-2012-00234716

Nevala, N., Pehkonen, I., Koskela, I., Ruusuvuori, J., \& Anttila, H. (2015). Workplace Accommodation Among Persons with Disabilities: A Systematic Review of Its Effectiveness and Barriers or Facilitators. Journal of Occupational Rehabilitation, 25(2), 432-448. https://doi.org/10.1007/s10926-0149548-z

Purnomo, H., Giyono, E., \& Apsari, A. E. (2017). The use of macro-ergonomic work system designs to reduce musculoskeletal disorders and injury risk in training. South African Journal of Industrial Engineering, 28(1), 47-56. https://doi.org/10.7166/28-1-1600

Shier, M., Graham, J. R., \& Jones, M. E. (2009). Barriers to employment as experienced by disabled people: A qualitative analysis in Calgary and
Regina, Canada. Disability and Society, 24(1),

63-75. https://doi.org/10.1080/09687590802535 485

Solovieva, T. I., Dowler, D. L., \& Walls, R. T. (2011). Employer benefits from making workplace accommodations. Disability and Health Journal, 4(1), 39-45. https://doi.org/10.1016/j.dhjo.2010.03.00 1

Solovieva, T. I., Walls, R. T., Hendricks, D. J., \& Dowler, D. L. (2009). Cost of workplace accommodations for individuals with disabilities: with or without personal assistance services. Disability and Health Journal, 2(4), 196205.

https://doi.org/10.1016/j.dhjo.2009.04.00 2

Stanton, N., Hedge, A., Brookhuis, K., Salas, E., \& Hendrick, H. (2004). Human Factors and Ergonomics Methods. In Handbook of Human Factors and Ergonomics Methods. CRC Press. https://doi.org/10.1201/9780203489925.c h1 